\title{
Embodied civic education: The corporeality of a civil body politic
}

\author{
Donna Paoletti Phillips
}

Abstract: This study explores the lived experience of democratic civic education for middle school students. Grounded in the tradition of hermeneutic phenomenology as guided by Heidegger (1962), Gadamer (1960/2003), Casey (1993), and Levinas (1961/2004), among others, the framework for conducting action-sensitive research, as described by van Manen (2003), guides this inquiry as I endeavor to uncover what it means for students to embody civic education. Twenty-nine students are taped engaging in discussions, debates, simulations, and other civic education. Twelve students self-select to engage in reflective writing and conversations about their experiences.

The existential theme of lived body emerges from this inquiry. The importance of embodying one's learning, as well as connecting physically and socially to one's society are apparent. The students' learning through their corporeal experience serves to create the civil body politic of the classroom and inform their behavior outside of the classroom. Insights from this study may inform curriculum theorists and developers, policy-makers, and classroom teachers. Recommendations are made to transform the social studies for students to capitalize on their bodily experiences within the classroom so that they may grow in their role as a citizen. Students may then embody the ideals essential in civic education and democratic societies.

Key words: Civic Education, Social Studies, Curriculum, Pedagogy, High School, Phenomenology, Democracy, Corporeality, Embodiment

\section{The corporeality of a civil body politic}

We shall need to reawaken our experience of the world as it appears to us in so far as we are in the world through our body, 
and in so far as we perceive the world with our body. (MerleauPonty, 1945/2005 p. 239).

This study explores van Manen's (2003) fourth existential, the lived body or corporeality of civic education. This prominent theme emerges as students describe their experiences in civic education. The role of the body, and more importantly, the importance of the chance to "embody" one's learning in civic education cannot be overemphasized. As Branson (2003) reminds us:

Some scholars claim that knowledge of the values and principles of democracy may be the most significant component of education for democratic citizenship, because when democratic norms are well understood they may have a kind of "grip on the mind" that makes them operate at a deeply internalized if not unconscious level (p. 5).

I take this notion one step further and suggest that civic education establishes not only a "grip on the mind" but also a grip on the body. When students embody their learning in civic education, they become the democratic values about which they are learning. Thus students who embody their civic education become actors for social justice, equality, and commitment in society.

\section{The body historic}

In the class, we started the year simulating the voyage of the Mayflower and students drafted their own version of the Mayflower Compact. As such, we created a social contract within the classroom. In the 1620 Mayflower Compact we find the reference to the "civil body politic:"

To covenant and combine ourselves together into a civil Body Politick, for our better Ordering and Preservation...(Mayflower Compact, 1620, as posted on www.law.ou.edu/hist/mayflow. $\mathrm{htm})$

In calling for the formation of a civil body politic, this first example of democracy in the new world calls to mind the fact that people are physically together in a society. The analogy of the body to society has its roots as far back as the ancient Greeks and Romans. Hale (2003), for example, notes, "Plato characterizes the highest good as a peaceful, friendly state, like 
a healthy body that does not require medical attention (p. 69). What parts of the body are analogous to the features of a civil society? When students describe their experiences in the classroom as emanating from their body, how does this help us understand their lived experience of civic education? What connections are they making to the larger civil society, to each other, to their own bodies as they bodily experience their learning? As Todes (2001) states:

Our body also plays a fundamental role in our impersonal sense of social identification with "fellow-citizens" whom we may never have met. ...The irrepressible metaphor for society as the "body politic" (as in Plato, Aristotle, St. Thomas, Hobbes, Hegel, Spencer) bears some witness that the features of civil society may reflect those of our individual body. (p. 3)

Lakoff and Johnson (1980) further elucidate, "Our experiences with physical objects (especially our own bodies) provide the basis for an extraordinarily wide variety of ontological metaphors. (p. 25) Thus with these thoughts and questions in mind that I return to the social studies classroom to uncover the lived language of students who have combined themselves in a civil body politic for the purposes of civic education.

\section{Every body in the classroom}

Our own body is in the world as the heart is in the organism: it keeps the visible spectacle constantly alive, it breathes life into it and sustains it inwardly, and with it forms a system. (MerleauPonty, 1945/2005, p. 235).

As Merleau-Ponty suggests, we are always bodily in the world. Students are present in our classrooms physically, as well as intellectually and emotionally. Casey (1993) explains, "This body has everything to do with the transformation of a mere site into a dwelling place. Indeed, bodies build places". (p. 116) Additionally, ontological metaphors such as the "mind is an entity" (Lakoff \& Johnson, 1980) develop meaning through experiences.

As a teacher arranges her room at the beginning of the year for incoming students, she imagines the bodies that will soon occupy the chairs and desks. How will the students move throughout the room? What will it mean to them to be seated physically next to someone else: a friend, an acquaintance, a stranger? The site of the classroom will transform into the place of learning and activity once the students' bodies inhabit it. 
The essence of lived body, however, goes beyond the acknowledgement of the physicality of their doing and being in civic education. Embodiment lends a much deeper meaning to the students' experiences. Csordas (1999) explains:

It is when we begin to think of the body as being-in-the-world that we find ourselves no longer interested in the body per se, but in embodiment as an existential condition. (p. 147)

Thus the uncovering of the students' experiences of lived body serves as a conduit through which we can more fully examine how students are civicly in the world, and how civic education shapes their being-in-the-world. Ultimately, the students' corporeal experience informs their decisions as citizens. To study embodiment does not simply mean to attune to the students' use of idiomatic phrases and references to the body. Rather, how does their use of such language help me understand the "twinge in the gut" they experience when recalling their lived experiences in civic education (Csordas, 1999, p. 149)? Furthermore, how does the body, its parts and actions serve as a metaphor for the students' civic education and how does this metaphorical thinking shape their experiences and thus civic dispositions?

\section{Off the top of the head}

As Merleau-Ponty (1945/2005) asserts, we do not just take up space, we inhabit it. Sartre (1943/1995) claims, "I exist in my body" (p. 378). What is essential in civic education as related to middle school students' lived body? One place to start is at the top of the body, the head. Some students claim that they experience their learning as if "off the tops of (their) heads," or within their heads.

\section{Layers of Civic Education}

As related to civic engagement, the students, as part of a simulated congressional hearing competition must be ready to answer follow-up questions from the judges after they deliver their prepared testimony. To do this, the students spend a large portion of their time researching historical events, current issues and constitutional examples that relate to their topic. Bobby's group, for example, testifies on the role of political parties, and as such, needs to be able to speak about the impact of political parties on our democratic government and opportunities provided for people to participate. Bobby describes what it is like to be able to engage in such conversations, with each other and with the judges. He states: 
Well, I have all my stuff ready. I guess it is just there are these follow-up questions they (his group members) have to do and ...they can come up with it within their heads like at the last minute. (Bobby)

Bobby references the part of the body where thinking takes place, the head. What does it mean to answer off the top of one's head? This idiomatic phrase conjures the image of knowledge piled up in layers ready to be peeled off. The knowledge is ready and waiting for the right question. But the student is not aware of it and can only access it when the right question is asked. How does thinking "off the top of one's head" contribute to the experience of civic education?

Following the "Conduit Metaphor" of experience Michael Reddy (1979) explains that ideas are objects, linguistic expressions are containers, and communication is sending (Lakoff, 1980). In this vein Bobby conceptualizes his experience of follow-up questioning as idea as objects students create in their own heads, the container for their linguistic expressions, ready to be sent or conveyed to the judges.

\section{Civic Education Looking Up}

A further layer in the orientational metaphor is the notion of " $u p$ is positive." Lakoff and Johnson (1980) give some examples if this in use such as "She'll rise to the top" and "Things are looking up." (p. 26) in Bobby's own words, the students "came up with" answers. Lakoff and Johnson assert that the assigning of such metaphorical orientations is not arbitrary, but rather "They have a basis in physical and cultural experience." That "up" is good, more, and forceful is no coincidence. When Bobby explains that ideas are made up in the head his experience of the follow-up questioning takes on a metaphorical meaning of adding force to his civic knowledge and learning. Applying this back to the conduit metaphor, Bobby and other students now have their civic knowledge (linguistics expressions) contained in their head which are communicated or "sent" to others. In this way the students embody their civic education as they themselves are the conduits of civic knowledge, imparting it upon their audience.

When students look outside of their own knowledge base and research historical and current events to apply to our constitutional principles and then engage in conversation around this store of knowledge, they experience civic education. One of the questions to which Bobby and his group must respond "off the top of their heads" is, "Do you think the Supreme Court should have the power to declare an act of Congress unconstitutional?" In response, his teammate states: 
I believe that the Supreme Court should have the power to say that an act of the Congress is unconstitutional. Since the Congress has the power to make laws, they have a good amount of power. But, since the Supreme Court has the power to tell whether or not this law is good, if the Congress makes a bad law then the Supreme Court should have the power to say that their act is unconstitutional...

Being able to access this knowledge, off the top of one's head, serves the purposes of civic education in that Bobby and his team are able to recognize and name times when the government must intervene to protect human rights. Outside of the classroom, when Bobby sees or hears about an abuse of human rights, perhaps he will be able to speak up (off the top of his head) to protect his and others' rights. Speaking "off the top of one's head" implies a lived meaning waiting to be accessed when faced with a situation that calls forth such a bodily response. Furthermore, embodying the metaphor of "making up answers" gives Bobby and his classmates a disposition to have confidence and force in their civic knowledge.

\section{Free of Calculation}

According to the Free Idiomatic Dictionary, "off the top of my head" means "from quick recollection, or as an approximation; without research or calculation" (http://www.thefreedictionary.com/). This kind of thinking does not call for the effort, however, that Bobby has described he and his team have given their project, and yet it is still an instance "free of calculation." Perhaps when one learns something at this depth, their new knowledge is experienced as if it did not require any effort to call it forth. Perhaps there is also a movement from the head to the heart, as moral claims of rightness are made in the body. A quick response comes from a sense of commitment to what is "right" action.

In civic life, Bobby's knowledge of political parties and his experience speaking off the top of his head about it will lead him to take "right" actions and join a political party, vote, and engage in conversations with other citizens about the political topics he came across during his research. If citizens can speak "off the top of their heads" on a topic, this indicates a physical connection and ownership of the civic knowledge and disposition and perhaps they are more likely to maintain their civic engagement.

Are we freer to approximate knowledge in a democracy? Furthermore, how does the rest of his body respond when one is free to approximate knowledge 
and not expected to be fully accurate? Perhaps this is when learning takes place, in the space created "off the top of one's head" where one is permitted to take risks and make mistakes. And yet, what is the responsibility for "right" thinking that one justifies when the quickness of the moment has passed?

\section{Stuck in the Head}

Jay's experience of learning in civic education is a variation on the use of the head in learning. He remembers because it is "stuck" in his head. Jay explains how he learned during the Simulated Hearing preparation.

This type of learning was very good because I learned about my topic researching and reading my speech so many times it got stuck in my head. What got stuck in my head was the responsibilities of a good citizen. (Jay)

Drawing once again on the conduit metaphor, Jay, in contrast to Bobby, names the head as the place where the knowledge got "stuck." For Bobby, the knowledge and memories rested there but came out when elicited. For Jay, the knowledge is also in his head, but he portrays a more permanent, less fluid arrangement. Is he able to access it the way Bobby describes? Jay, too, connects his doing, "researching and reading so many times," with his learning. Because Jay does not experience his learning as if off the top of the head, but rather "stuck" in the head, perhaps his recollections are more tied to accuracy and calculation than those of Bobby. Is one type of learning more valid than another? Does Jay feel the same sense of freedom, of approximation that Bobby may experience in being able to answer off the top of his head?

I turn to Jay's performance in the simulated congressional hearing. As he states in our conversation, the responsibilities of good citizens are what "stuck in his head." In their prepared testimony, he and his team assert:

In order to be a 'good' citizen, you should be informed by keeping up with current events. Moreover, a citizen in a democracy should be an active participant in society. This includes voting, cleaning the environment, doing various community services. Lastly, a citizen has the right to attempt to change the law, but must obey the current law until it is actually changed. (Written testimony, unit 6) 
Thus, for Jay, his experience of civic education seems to be a cementing of knowledge of good citizenship. From his experiences in the classroom, Jay now embodies good citizenship as someone who will "keep up with current events," participate in community services, and someday vote. In the followup questioning round of the simulated hearing, Jay demonstrates this civicmindedness when he responds to the judge's question by explaining how young people can get involved in government. Jay later reflects:

They asked us a question on how a young person can get involved with voting and I said you guys involved us here [referring to the judges in the hearing]. Also I stayed up watching the news... and the Rock the Vote on MTV... That was a good question. (Jay)

Casey (1993) names the body as the place wherein memories are stored. He states, "The things of memory remain with me, within me. They occupy interior (and doubtless also neurological) places.... I remain with them as well by returning to them in diverse acts of remembering" (p. 129). This type of remembering may be what Jay experiences as he describes the knowledge that is now "stuck in his head," knowledge of what it means to be a good citizen. His memories of the simulated hearing, his preparation for it and the confidence he felt answering the judges' questions occupy interior places in his body, and he may remain with them when he is called to remember them. This "bearing in mind" or as Casey (1993) names it, "bearing in body" (p. 129) speaks to the lived body experience of civic education. When Jay turns 18 and can vote or when he is presented with an opportunity to participate in community service, his experiences with the simulated hearing that have "stuck in his head" perhaps may prompt him to act in a bodily way; to go to the voting polls, engage in a political discussion, or join a protest.

Living out the conduit metaphor, we find once again, the students themselves embody their own civic education as they are delivering their messages which have been contained, or "stuck" in their heads as a product of their civic learning.

\section{To the bottom of the feet}

But the head is not the only place where memories and civic knowledge may be stored in the body. Students also name their experience in civic education, particularly during the follow-up questioning during the Simulated Congressional Hearing, as one of learning to "think on their feet." 
We can't use exactly current events like all your research you did because they might not ask those specific questions so it was really hard because you had to think on your feet. (Kelly)

During the follow-up questions I found out that I was good at thinking on my feet. When asked hard questions that I hadn't rehearsed I was quick at coming up with an answer [and] giving an example. (Kate)

One part of the hearing that taught me something was the follow-up questions. I learned how important it is to be able to think on my feet. I will remember this in the future because it is so important to be able to do this and I will need it many times throughout my life. (Brandon)

In their participation in debates and the Simulated Hearing, students had to "think on their feet." What does it mean to be able to do this? The students seem to experience this in a few ways. Kelly's experience relates to the idea of not knowing, but not knowing you know until challenged. Kelly experiences this aspect of civic education as she forms answers to the judges' questions. As she states, she prepared for the hearing by learning about current events, but she knew that the judges could ask her anything. One such question from the judges was:

This week the identity of Deep Throat, a very high-ranking official in the F.B.I., was revealed. Should he be prosecuted for violating confidentiality or does his freedom of speech protect him?

Kelly replies:

I agree he should be prosecuted because he was supposed to remain confidential. Just like how in school if you try to publish something with freedom of the press, you can still get in trouble for violating the honor code or school rules. (Kelly)

Kelly actively connects a current event, about which she knows little and admits to having to think about on her feet, with her knowledge of her first amendment rights and their limitations. Turning to Westheimer and Kahn's (2004) theory of three types of citizenship, perhaps Kelly is more apt to participate in her society since she has been called to think on her feet. In their model, the second type of citizen, those who participate, may be encou- 
raged based on her experience of civic education in the simulated hearing. I imagine someone jumping up at the sound of a question and once up, not returning to a seated stance. Kelly, in forming opinions and ideas about such current events, experiences civic education as a value engagement. Now that she has been afforded the opportunity to think on her feet about these and other issues, might she act in society in a more thoughtful, conscious way?

\section{Clarifying on Foot}

Brandon recognizes the phenomenon of thinking on his feet as positively stating he knows he "will need it many times throughout my life." Kelly recognizes the importance of being able to "think on her feet." Kate found out she was "good at thinking on her feet" when the judges ask her to clarify her understanding of her rights.

Judge: What is the difference between natural rights and the rights given up in forming a social compact?

Kate: There is not much difference. You have to give up some liberties and property to make sure most of it is protected.

Judge: But isn't property a natural right?

Kate: If you didn't give up some of it, you would be at risk of losing all of it.

Judge: Where does the risk come from?

As the judges press her, she is forced to think on her feet, beyond what she had explicitly prepared. This experience is significant in civic education because it is exactly the experience active citizens are faced with in society. As Jay and his team assert in their prepared testimony, good citizens stay informed on current events. Students who are able to think on their feet might become citizens who think on their feet, in conversations with other citizens and in deciding to take action when they witness injustices. In "thinking on their feet" students make new connections between ideas, and thus arrive at new understandings and dispositions, which they carry with them out into society. In this way, moving beyond the metaphor, students can come to embody their learning.

Off the tops of their heads and on their feet, before their fellow classmates in debates, and before judges in the simulated hearing, students are con- 
structing new understandings of what it means to live in a civil society from their storehouse of information, experiences, and beliefs. They actively construct knowledge through their bodily action.

Heidegger (1993b) ponders, "What is it that calls us, as it were, commands us to think? What is it that calls us into thinking?" (p. 383). Civic education allows students such Kate, attending to their experiences in the classroom, to be called into thinking outside of the classroom. Kate describes how her experiences in civic education shape who she is outside of the classroom.

My learning experiences weren't limited to that. For instance when we learned about how the environment affected people's lives and where they lived, we also learned that [it] often played a role in determining people's college choices and careers. After that we were given the opportunity to speculate about which colleges and careers would suit us. ... I learned more about life in world studies than I had ever imagined. (Kate)

When her values are challenged by events and interactions outside of the classroom, she now has a lived experience from which to draw to find the strength and body memory to think on her feet and act in a civilly responsive way.

\section{Stand and deliver}

Casey (1993) claims "bodies build places." It is for human bodies that buildings are constructed and these buildings are built for bodies to be able to stand up. Students in civic education have their own sense of what it means to stand up, in and out of the classroom. When asked to recall an experience in civic education, Jamilla shares:

When we had the simulation that we had to pay tax for the paper, that really showed how you could stand up for your rights and how if you did try, it could be changed. And how some people stood in with the government or the king and others just protested and got their rights. (Jamilla)

Jamilla describes a time when students spontaneously decided to protest a fake tax the eighth grade teachers levied so they could experience the injustice similar to what the colonists may have felt leading to the American Revolution. It was an unpremeditated move on the part of the students to protest by physically leaving the classroom and "standing up" for their rights. Some stu- 
dents showed their discontent by forming and signing petitions. But Jamilla connects protecting her rights with physically standing up for them by joining in the more active protest. Several of her classmates actually stood up and left the classroom marching down the hall chanting against the "tax." In contrast, those who did not want to protest, still "stood in," remaining in the classroom. She explains how she connects her experience in "standing up" during the simulation with a real-life situation outside of the social studies class.

It's kind of like when we did the simulation with the tax you kind of saw how you could stand up for your rights and things like that so when in one of my [other] classes, it's a student's right that you can stand up and a teacher can't say anything rude or offending about you. So I stood up for that and I thought that kind of goes with the simulation because you learn how to stand up for yourself and what to do in those cases. (Jamilla)

Lakoff and Johnson (1980) explain that the orientational metaphor "up" refers to having control so it is no surprise that Jamilla and others equate standing "up" for their rights as a form of empowerment. "A metaphor can serve as a vehicle for understanding a concept only by virtue of its experiential basis. (Lakoff and Johnson, 1980, p. 18) Thus Jamilla's experience of empowerment through standing up is experienced through th lived metaphor.

\section{A republic of many voices}

Was it the physical act of standing up during the simulation that allowed Jamilla to stand up for herself in other cases in other classrooms? If so, this connection is not limited to classroom behavior. As she continues to describe, Jamilla finds herself standing up for her rights at home as well.

At home my brother usually tries to get me in trouble... So whenever he does play a prank on me I'll use different proofs of evidence like things we had in the debate and make compelling arguments and say like I have the right to stand up for myself. (Jamilla)

Once again Jamilla is empowered through the lived metaphor that argument is war where all the elements of war as it relates to argumentation are present. Specifically, Jamilla recounts experiencing the conflict and "marshalling her forces" or using different "proofs of evidence" in her interaction with her brother. (Lakoff \& Johnson, 1980, p. 79) Jamilla takes a stand in 
her own family and consequently finds her voice. Ayers (2004) asserts that allowing students to find their voice is essential to teaching toward freedom. He states:

The first commitment a teacher teaching toward freedom makes is a pledge to take the side of the student... A second, closely linked commitment is to create a space where a republic of many voices might come to life... (p. 69)

In this light, Jamilla has been afforded the opportunity through her experience in civic education to allow her voice to come to life, not only in the classroom, but also at home within her family community. It is through her voice that she has come to embody her civic education.

Ayers (2004) continues to describe the "republic of many voices": The freedom teacher vows to build an environment where human beings can face one another authentically and without masks, a place of invitation, fascination, interest, and promise. (p. 69)

This environment that Ayers (2004) describes is the classroom space essential to civic education. Through the simulation, Jamilla is able to face her fellow classmates authentically, and as a result, finds her voice, which allows her to stand up for her rights and express her views. In this "republic of many voices" the students who occupy the physical space in the classroom find their voices, thus support each other as they feel compelled to take a stand. Jamilla has a chance now to embody the third type of citizenship Westheimer and Kahne (2004) describe, which is the "Justice-oriented Citizen."

\section{Civic Education Stands}

What does the physical act of standing do to transform students' learning? As one of the etymological roots of "stand" is "place" or "position" (Barnhart, 1988, p. 1059), perhaps standing up for one's rights gives students a new sense of their place or position in the classroom, families or in society. From their elevated position, do students feel a greater sense of power, of claim to a place in society or in the classroom? When they stand, does their physical action automatically transform their self-perception? And referring back to Casey, how does the students' act of standing up add to the transformation of the site of the classroom to a place? As place is an etymological root of the word stand, perhaps students taking a stand means creating a place for themselves, a place in the classroom, a place in society. 
Jamilla's descriptions bring me to an excerpt of a poem by D. H. Lawrence (1929):

\section{Stand Up!}

Stand up for something different, and have a little fun

fighting for something worth fighting for

before you've done.

Stand up for a new arrangement

for a chance of life all round,

for freedom, and the fun of living

bust in, and hold the ground! (no pagination)

When Jamilla experiences injustice at the hands of her teachers or other family members, she pictures "something different" and acts in pursuance of that end. In her retelling of these experiences, she was almost gleeful, able to share her triumph over those who would hold her down and take away her rights. Her rights as a student in different classes, as well as her rights as a member of her family, are "worth fighting for" and therefore she stands up for them.

Stand up, sit down, fight, fight, fight!

What else can teachers do as instruments of civic education to allow other students to feel the same sense of urgency and efficacy that Jamilla experiences in standing up for her rights? As the last stanza of the poem implies, standing up for justice or a "new arrangement" is standing up for "a chance of life all around." Where would American society be if it were not for those who did stand up in the face of adversity? One only need to turn to the 1950's and 1960's Civil Rights Movements for examples of those who stood up for their rights and who fought for "new arrangements" and a "chance of life."

What life does Jamilla envision as she stands up, sometimes to her own peril, for her rights in the face of adults who control her classroom experiences, grades and social opportunities? Jamilla sees these risks and still feels supported to take them by "standing up."

One of the things that I learned from being in the system is that you should never allow the teacher or any authority power push you down. Like if they say you do something that is wrong, you need to stand up. I think students don't realize authoritarian power until later. (Jamilla) 
Jamilla seems to be invoking the last line of Lawrence's (1929) poem that students need to "bust in, and hold the ground!" Students do not always recognize the authoritarian power over them and therefore do not act at the time. Only later do they realize that they should have "stood up" for their rights, "for freedom, for fun all around."

\section{Chance of Life All Around}

Looking back to her first experience "standing up" for her rights we remember that Jamilla is afforded the chance to stand up physically during a simulation. How does the act of physically standing up affect the students' understanding of what it means to stand up for their rights, for "jolly justice" for freedom? As Casey (1993) notes:

The mere fact that we stand up in buildings represents another dimension of dwelling-as-residing. Although we sit and recline, we stand upon entering and leaving and sometimes during our entire stay (stay and stand are etymological cousins). In a built place, we continually take a stand... (p. 117)

Jamilla's opportunity to take a stand in class led to a deepening of her sense of dwelling-as-residing in the classroom. This may in turn forge a stronger connection between herself and her classmates. Did she notice who took a stand with her? What connections did she feel to those who stood with her? Casey (1993) goes on to state:

When human beings stand in rooms, they are especially sensitive to their height, which echoes their own uprightness as beings. ...Moreover, to be upright signifies self-assertion and ambitious reaching up and out...just as it connotes moral forthrightness... (p. 117)

Perhaps Jamilla and her fellow classmates experienced this sense of moral forthrightness and self-assertion. They certainly were asserting their rights in their actions and in their words, and the physical act of standing gave form to their intentions. Jamilla and her classmates were morally and physically "reaching up and out." Thus to have the opportunity to "stand up" in the classroom may foster students' embodiment of such civic education ideals of self-assertion and moral forthrightness. 


\section{Standing for oneself}

Fletcher takes a stand in a different way. He relates a time when his classmates did not believe he would follow through on his part of the group process in preparing for the Simulated Congressional Hearing. He explains why he was motivated to do extra work for the benefit of his group.

I could take it [the prepared testimony], I could bring it home and bring a new one in and say 'hey I made a few changes.' I could do that but I was hoping I could do something sooner. Because this is what I am standing for. I am "unit two" and this is what I am supposed to do. It is what I need to do. ... It is what I need to know. I have to do it. I think I have to do it more for myself to know that I have trust and stuff that everybody knows. (Fletcher)

Fletcher's experience of standing in civic education has to do with naming a place or position for himself to be in relation to his group members. Referring back to the etymological root of "stand" we remember that it is a synonym for position. Fletcher experiences a disparity between his "standing" in his group and what he knew he was capable of contributing. By doing the extra work, he hoped to improve his standing or position in his group. Fletcher seeks to become the whole of his unit, his team. He wants his teammates to see that despite his absence, he is as much a part of the group as they are. He is "taking a stand" in order to prove (or im-prove) his standing in the group.

Moving beyond the mere physical action of standing, I find evidence of Fletcher embodying his civic education. He asserts, "I am unit two." What does this mean for Fletcher? His testimony is about the principles of good government described in the Declaration of Independence and their relevance today. In it he asserts:

The first and most important rule of good government is "All men are created equal, ...Good government protects its people at all times and can be adjusted... Good government also has the ideas of Rule of law. Rule of law is when everyone in a society has the same rights and laws to follow. (Written testimony, Unit 2)

For Fletcher to take a stand and embody the ideals of good government, he is adding to the democratic culture by helping uphold rule of law. His "stand" is that the most important purpose of government is to protect natural rights and to promote equality. In standing for Unit Two in class, Fletcher stands for these ideals outside of class. 
Furthermore, Fletcher, in "taking a stand" and embodying the goals of his group, seeks to enrich his Being. As a member of the class and his team he dwells with his classmates who depend on him for their success, not just in their performance in the Simulated hearing, or for a grade, but also, as Fletcher puts it, to share the "stuff everybody knows." Fletcher experiences his citizenship in the classroom as something for which he has to fight to prove his worthiness. Outside of the classroom, perhaps he will approach his citizenship in the same way. Fletcher will remember what it was like to "stand for" something and be able to re-embody the experience to "stand for" something important in his community.

\section{A civil body politic at hand}

The most salient aspect of the students' civic education was their bodily experience of civic education as "hands-on." Dewey (1916/2006) discusses the role of the hand in education as he states:

The lips and vocal organs, and the hands, have to be used to reproduce in speech and writing what has been stowed away. The senses are then regarded as a kind of mysterious conduit through which information is conducted from the external world into the mind; they are spoken of as gateways and avenues of knowledge. (p. 89)

The hands are "gateways and avenues" of knowledge. Dewey does not posit that knowledge is acquired only through the eyes and ears, but rather through all the senses. The hands as well as the other senses bring the outside world into the mind. Conversely, Dewey (1897/2004) states:

The muscles of eye, hand, and vocal organs accordingly have to be trained to act as pipes for carrying knowledge back out of the mind into external action. For it happens that using the muscles repeatedly in the same way fixes in them an automatic tendency to repeat. (p. 89)

In this way, the hand, eyes, and voice are used to transport knowledge from the mind into external action. This action is what creates habits in "an automatic tendency to repeat." Civic educators are concerned with how students form certain "habits of mind." These habits include civic virtue, volunteerism, critical thinking, and other civic-minded actions necessary to maintain a democratic republic. 


\section{Civic education handed over}

Teaching is filled with mundane aspects involving the hand such as handwriting, hand-outs, and hand-raising. Students, however, do not refer to these uses of the hand when they re-member their experiences in civic education. Instead, they describe their learning as "hands-on."

D. Breault (2005), reflecting on Dewey's understanding of the necessity for students to be actively engaged in their learning, states:

[There are] critical prerequisites for the kind of active learning Dewey described throughout his work: thoughtful planning, solid understanding of the subject matter, a willingness to experience ambiguity in the learning context, and a relationship of mutual trust between the teacher and the students. (p. 19)

It is this kind of hands-on experience that students in civic education have. For example, in describing their preparation for and participation in the Simulated Congressional Hearing, many students refer to a hands-on mode of learning.

This type of learning was totally different from the other types because it was more hands-on. The students were allowed to be more independent and the teacher trusted the students to work without her constantly watching over us. (Joy)

I like this type of learning better. It is more hands on-basically, the teacher stepped out of the way a little and we were in rule. It was a lot of fun. (Jamilla)

[In the] simulated congressional hearing itself I was able to put into my own words, and translate from others what it meant to me. I found it ...to have been pretty hands-on. (Sam)

The type of learning involved in this process is the best kind. It is hands-on. You have to find the information yourself, instead of listening to a teacher's lecture. It makes learning more fun, and definitely more interesting. (Bernie)

Hands-on learning is learning of "the best kind." It is a time when "the teacher steps out of the way" and students are "allowed to be more independent and the teacher trusts the students." These descriptions imply a trans- 
fer of power and ownership from the hands of the teacher to the hands of the students. When students experience their learning as hands-on, they are "handed-over" this power and allowed to make decisions for themselves. Teachers "step aside" and invite students to have a hand in their education. This evokes an image of a teacher physically stepping aside with the sweep of their hands as they make way for the students to enter into their own learning.

Heidegger (1993b) explains that when teachers allow for letting learn, their pedagogy "often produces the impression that we really learn nothing from him, if by 'learning' we now automatically understand merely the procurement of useful information" (p. 380). This speaks to the students' perceptions of the teacher "not teaching" during the simulated hearing preparation or during other hands-on activities. Dewey asks:

Why is it, in spite of the fact that teaching by pouring in, learning by passive absorption, are universally condemned, that they are still so entrenched in practice? (as cited in D. Breault, 2005, p. 18)

Indeed, as student after student relays their experience of civic education and reflects upon the times when they are most active in their own learning, Dewey's decades old question is even more relevant today than ever!

\section{A Hand in teaching}

Furthermore, as D. Breault (2005) interpreting Dewey explains, just as the students experience a sense of their teacher's trust in them, so too, the students have to trust the teacher to enter into this hands-on arena. I picture the teacher extending a hand and helping the students cross a border or boundary, where students are not always permitted to go: the place of authority or authorship in their education. The students are now the teachers. They now have a hand in their own learning. As Jamilla and Kelly reflect, this type of learning they re-member.

Kelly: Because when you actually find your research you're like oh, I found that out. When you teach us we kind of forget after a while.

Jamilla: It is hands-on like, you are...

Kelly: You are the teacher 
They connect the act of teaching themselves with re-membering because they "had a hand" in finding the information.

Lakoff and Johnson (1980) assert that a metaphorical concept must fit the experience. "It is by means of conceptualizing our experiences in this manner that we pick out the "important" aspects of an experience. And by picking out what is "important" in an experience, we can categorize the experience, understand it, and remember it." (p. 83) Thus the students have chosen the hand and their experience in civic education as a metaphor for their civic learning. This is how they re-member their civic learning, through their hand.

\section{A hand turned upward}

I continue to ask what the choice of the term "hands-on" means for civic education. What is the role of the hand in civic education? The last lines of the poem, A Hand, by Jane Hirshfield (2001) may help to elucidate this connection.

A hand turned upward holds only a single, transparent question. Unanswerable, humming like bees, it rises, swarms, departs. (http://www.poets. org/viewmedia.php/prmMID/19011)

As these lines imply the hand is not the flesh and bone, nor is it the products which it helps to shape. Similarly, the essence of the hands-on experience for students in civic education is not in the materials they actually use, nor the physical labor of using their hands. Rather, it is in the opening of possibilities this experience allows. Many students savor this opportunity. Other students feel anxious when the answers are not readily "at hand."

\section{Presence-at-hand}

In discussion of the essence of being, Heidegger (1993a) explains:

Legein itself or noein - the simple apprehension of something at hand in its pure being at hand...has the Temporal structure of a pure "making present" of something. Beings, which show themselves in and for this making present and which are understood as beings proper, are accordingly interpreted with regard to the present; that is to say they are conceived as presence (ousia). (p. 70)

As students work in hands-on ways in civic education, they are becoming more present to their learning, to each other and to themselves. As stu- 
dents experience their classmates and their own presence in this authentic way, they are able to transform from a passive recipient of civic education to an active participant in civic education, and thus in society. Hands-on experiences, in making civic education more present to the students, roots the students in the present, while drawing upon the past. Thus rooted together and experiencing civic education in this hands-on presenting way, students come together in the presence of each other in their civil body politic.

\section{Readiness-to-hand}

Another aspect of the hand Heidegger (1962) refers to is "readinessto-hand" or zuhanden. By this, he means involvement. He relates this to one's Being-in-the-world, stating:

Dasein, in its familiarity with significance, is the ontical condition for the possibility of discovering entities which are encountered in a world with involvement (readiness-to-hand) as their kind of Being, and which can make themselves known as they are in themselves. (p. 120)

Students experience "readiness-to-hand," or involvement in civic education when they work in hands-on ways with each other. The opportunity for this involvement allows students the chance to assert their being to one another and come more authentically into themselves. Indeed, just as students' presence may be reaffirmed by working together in this way, the chance to work in a hands-on way also affords students the opportunity to reaffirm their involvement. As future citizens, we want our students to experience this sense of commitment to one another and their community.

\section{The question at hand}

How does hands-on learning, with its "unanswerable" question, a hand turned upward, influence the student? Are students more willing to dwell within the questions, not beholden to the "right" answers? The hand turned upward allows the free exchange of ideas and views; "humming like bees, it rises, swarms, departs." So, too, does the classroom sound like humming bees as students are engaged in hands-on work. Questions shoot back and forth between students like bees. Bodies are in motion. Students are in and out of their seats moving to talk to each other to reach their hands out for more resources, to ask and answer each other's questions. 
I think about the physicality of citizenship itself. Societies come to be through the physical organization and interaction of the people. Much like in the classroom, people must work "hand-in-hand" with one another and with their government for democracy to work. They must "have a hand" in politics for their voice to be heard and for democracy to be truly a "government of the people." "Swarms" of people protest, gather for rallies, meet in town halls and show up at polling places.

\section{A hand in voting}

What role does the hand play in how students acquire civic knowledge when they act in civic-minded ways? I now turn to more of the students' text to see how they perceive the use of their hands in their education. When asked to describe a time when they experienced civic education some students shared "hands-on" activities in which they had participated. For example, Kelly remembers a time when she voted.

When we got to vote, it was like really kind of refreshing because teachers usually choose who is going to be in charge and when we got to vote, it was really in the hands of the students to decide who they really thought was going to be the best captain. (Kelly)

Kelly experiences this aspect of democracy as something that was "in the hands of the students." What does putting decisions in the hands of the students do to shape their experience of civic education? Kelly states that it was refreshing to be "handed" this responsibility from the teacher. She feels a level of comfort in making this decision along with her classmates, believing that sometimes students make the best decisions about team partners, implying an attunement to the "civil body politic" that is the social studies classroom. For students to feel that they may make sound judgments for the benefit of the whole class also implies a connectedness between and among all the students. Will Kelly take this dispisition into her own hands to vote in national, state and local elections?

What does it mean to be a member of a civil body politic? The Mayflower passengers combined to from a civil body politic for "better order and preservation." Because not all the passengers on the ship were familiar to each other, they decided to come to an agreement with one another to organize their efforts and protect their rights. As such, they moved from being strangers to each other to fellow citizens combined for a common cause. Students in the same way make up a civil body politic in that they are 
among friends and strangers in the classroom. John Locke $(1620 / 2006)$ theorizes on this obligation as humans enter into a social contract with one another.

And thus every man [sic], by consenting with others to make one body politic under one government, puts himself under an obligation, to every one of that society... (sec. 97)

When students experience democracy in the classroom, through voting, protecting and defending theirs and each other's rights, and taking on responsibilities, they move from being strangers to citizens of the classroom as they reinforce their coming together in a civil body politic.

\section{Whole-Body Membership}

This membership is whole-body and one finds connections back to early political philosophers' notions of a civil body politic. Students experiencing civic education through their bodies comprise the civil body politic of the classroom. As Hale (2003) reminds us, "Seneca says that as it is unnatural for the hands to destroy the feet, so the need for harmony, love, and mutual protection causes mankind [sic] to protect individuals" (p. 69). Furthermore, there is no society without the physical people. Restating Parker's (2003) claim:

It is citizens who walk the paths to the public squares and, by walking them, create them. There, struggling to absorb as well as express, to listen as well as to be heard, they strive to communicate across their differences, recognizing them and joining them with deliberation. This is how publics come to be. (p. 11)

Publics and communities come to be by the physical joining of people together. In civic education, students approximate the experiences of deliberating for the common good, balancing their liberties and the obligations to the public, and problem-solving together. They are physical members of the group and, thus, their mere membership creates the civil body politic.

\section{Reliable actors in the world}

Looking forward, I ask how the students' bodily experiences shape the type of citizen they might become. Casey (2000) states: 
To be habitual is to have or hold one's being-in-the-world in certain ways, i.e., those determined precisely by one's settled dispositions to act in particular patterns. The presence of these dispositions means that our habitual actions help to constitute us as reliable actors in the world-to be counted on by others as well as to count on ourselves. (p. 150)

Civic education has the potential to encourage certain habits in students. As actors in a democracy, we need to be able to count on our fellow citizens to uphold the law, respect rights, speak out against injustice and participate in democratic processes. Students participating in civic education through their whole bodies have a chance to form such habits, and having experienced civic education through their lived body, hold their being-in-theworld in a certain way becoming reliable actors in the world. Whatever shape their being-in-the-world takes, it is through their corporeal experience in civic education that they have been able to transform and will in turn transform their own civil body politic.

\section{References}

Ayers, W. (2004). Teaching toward freedom: Moral commitment and ethical action in the classroom. Boston: Beacon Press

Barnhart, R. K. (1988). Chambers dictionary of etymology. New York: The H.W. Wilson Company.

Branson, M. (2003). The importance of promoting civic education. An Address to the $2^{\text {nd }}$ Annual Scholars Conference Sponsered by the Center for Civic Education. Pasedena, CA. Retrieved September 2006 from http://www.civiced.org

Breault, D. (2005). Work in school. In D. Breault, \& R. Breault, (Eds.). Experiencing Dewey: Insights for today's classroom. (pp. 18-20). Indianapolis, Kappa Delta Pi, International Honor Society in Education.

Casey, E. (1993). Getting back into place: Toward a renewed understanding of the place-world. Bloomington: Indiana University Press.

Casey, E. (2000). Remembering: A phenomenological study. Bloomington: Indiana University Press.

Center for Civic Education. (1998). We the people: The citizen and the Constitution: Teacher's guide, level II. Calabasas, CA.

Csordas, T. (1999). Embodiment and cultural phenomenology. In G. Weiss \& H. Haber, (Eds.), Perspectives on embodiment: The intersections of nature and culture. (pp. 143-162). New York: Routledge.

Dewey, J. (1897). My pedagogic creed. The School Journal, LIV (3), pp. 77-80. Retrieved November, 2004 from http:/ / www.infed.org/archives/e-texts/e-dew-pc.htm. Dewey, J. (1916) Democracy and education. Retrieved April 2006 from http:// en.wikisource.org/wiki/Democracy_and_Education\#The_Democratic_Conception_in_ Education 
Gutman, A. (1999). Democratic education. Princeton, NJ: Princeton University Press. Hale, D. (2003). Analogy of the body politic. The Dictionary of the History of Ideas Electronic Text Center. Retrieved July 2006 from http:/ / etext.virginia.edu/DicHist/ dict.html

Heidegger, M. (1962). Being and time. New York: Harper \& Row.

Heidegger, M (1993a). Introduction to being and time. In D.F. Krell (Ed.), Basic writings, (pp. 37-87) New York: HarperCollins. (Original work published 1927)

Heidegger, M. (1993b). What calls for thinking? In D.F. Krell (Ed.), Basic writings, (pp. 365-391) New York: HarperCollins. (Original work published 1954)

Hirshfield, J. (2001). A Hand. In Given sugar, given salt. HarperCollins. Retrieved October 2005, from http://www.poets.org/viewmedia.php/prmMID/ 19011

Lakoff, G. \& Johnson, M. (1980). Metaphors we live by. Chicago: University of Chicago Press.

Lawrence, D.H. (1929) Stand up! Retrieved April 2006 from Online text copyright (C) 2003, Ian Lancashire for the Department of English, University of Toronto.

Locke, J. (1620) Two treatises on civil government. Retrieved July 2006 from http:// www.lonang.com/exlibris/locke/loc-208.htm

Mayflower Compact. (1620) Retrieved August 2005 from www.law.ou.edu/hist/mayflow.htm

Merleau-Ponty, M. (2005). Phenomenology of perception (Routledge \& Kegan Paul Trans.). New York: Routledge Classics. (Original work published 1945)

Parker, W.C. (2003). Teaching democracy: Unity and diversity in public life. New York: Teachers College Press.

Reddy, M. (1979). The Conduit Metaphor. In A. Ortony, ed., Metaphor and Thought. Cambridge, England: At the University Press.

Sartre, J.P. (1995) Being and nothingness. An essay on phenomenological ontology (H. Barnes, Trans.). London: Routledge. (Original work published 1943)

Schubert, W. (2005). Active learning as reflective experience. In D. Breault, \& R. Breault (Eds.). Experiencing Dewey: Insights for today's classroom (pp. 12-16). Indianapolis, IN: Kappa Delta Pi , International Honor Society in Education.

Todes, S. (2001). Body and world. Cambridge, MA: The MIT Press.

Van Manen, M. (2003). Researching lived experience: Human science for and action sensitive pedagogy. London, Ontario: Althouse Press.

Westheimer, J., \& Kahne, J. (2004, summer). What kind of citizen? The politics of educating for democracy. American Educational Research Journal, 41 (2), 237-269.

\section{Author:}

Donna Paoletti Phillips, PhD.

University of Maryland College Park

James Hubert Blake High School

300 Norwood Road

Silver Spring, MD

email: Donna_Phillips@mcpsmd.org 